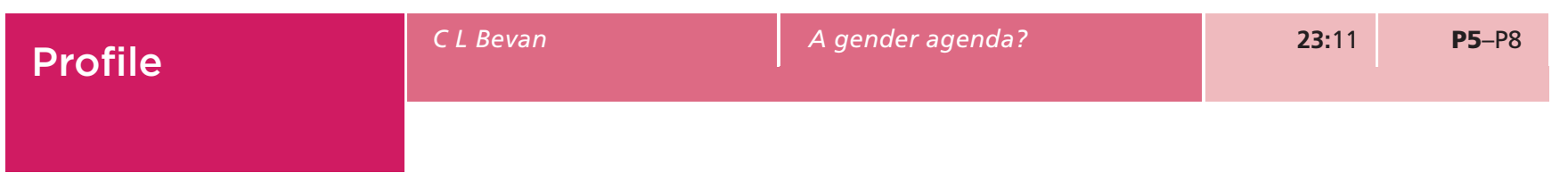

\title{
WOMEN IN CANCER PROFILE A gender agenda?
}

\section{Charlotte L Bevan}

Department of Surgery \& Cancer, Imperial College London, London, UK

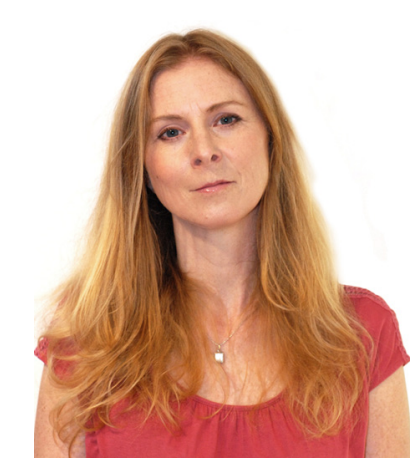

Correspondence

should be addressed

to C L Bevan

Email

charlotte.bevan@imperial.

ac.uk

Growing up, I never understood why so many people professed to have no interest in science. How could understanding how things work not be the most fascinating thing? And how we, as organisms, develop and function (or fail to) seemed to me the most fascinating thing of all. One of my most inspiring school teachers was the head of Biology, Dr Chris Haworth, who undertook to nurture my ambition to gain a place at 'Oxbridge' (no one from our comprehensive school in the far north of England had previously gone to either Cambridge or Oxford). I remember one lesson in which we came in to find dandelion leaves strewn around the room. It turned out they were all different, representing a fair proportion of the 250-odd species of dandelion on which, had I but appreciated it at the time, Dr Haworth was a recognised authority. Although many of my classmates flatly refused to see any difference between the leaves, it was my first introduction to genetic diversity. And speaking of diversity, I wanted to keep my options open so crammed in as many A level subjects as I could, from Applied Mathematics to English Literature, refusing to drop any despite the recommendations by career advisers and admission tutors.

This reluctance to specialise early made the Natural Sciences Tripos at Cambridge attractive to me, and I applied to Kings College. I knew very little about the colleges and picked Kings on the basis of its informality (no gowns required), beauty - and the fact that they gave me a free lunch when I went to visit. During my interview, I was asked to talk about any aspect of science that currently interested me (that will sound familiar to anyone who has been interviewed by me). As luck would have it, a few weeks earlier the BBC had screened 'Life Story', their excellent Horizon special on the discovery of the structure of DNA. Perhaps it was my enthusiasm for, and loquaciousness on, this subject that clinched me the offer from King's. So you might be forgiven for thinking the scene was set for me to take advantage of the unparalleled history and faculty that Cambridge offered in molecular biology, genetics and evolutionary biology. In the event, I applied and was accepted to study the physical sciences - and spent a year beforehand and my summer holidays working for British Nuclear Fuels plc., in a wide variety of roles from instrument calibration to health monitoring. I was destined to become a nuclear physicist, despite the unavoidable fact that the Physics labs were the furthest one could be from College and I stubbornly refused to ride a bike, whereas the Genetics and Biochemistry departments were just around the corner (and much more handy for pubs such as the Eagle, as one memorable scene in Life Story illustrates). However, at the end of my second year, I had to admit to myself that the course in Cell and Developmental Biology I had taken alongside the double Physics option was more interesting to me. I still do not know if my insistence on sticking with Physics to that point was a hangover from the days when I was the only girl in the Physics A-level class - the ratio was not quite as skewed at degree level, but still nowhere near parity. Either way, after a slight crisis, I decided to take Part II Genetics, and it was a wise decision.

This paper is part of a special section on Celebrating Women in Cancer Research. The Guest Editors for this section were Charis Eng and Deborah Marsh

Downloaded from Bioscientifica.com at 04/26/2023 11:08:50AM 
The Genetics department in the early 90s was an exciting and vibrant place to be, there was a lot to learn and, with apologies to my colleagues in Physics, the parties were a lot better (admittedly not as good as the Classics parties, which were the gold standard). It was during this year that I undertook my first substantial research project and met nuclear receptors for the first time, both formative experiences. I elected to do my project in the Drosophila laboratory under the renowned and redoubtable Michael Ashburner. It was a breeding experiment to determine whether two genes, mutations in which caused similar phenotypes, were in fact allelic, and a large part of it was counting newly hatched flies under anaesthetic. (The flies, not me, although as we used platforms that emitted the gas, and it often had to be done late into the night, I would often emerge from long stints feeling pretty light-headed and perhaps can be forgiven for describing my first foray into research as intoxicating). Looking back at the report we published in what must be one of the first open access journals, the Drosophila Information Service - I see that I must have counted (painstakingly, using a paintbrush) over 7000 flies. In retrospect, I see why that project was passed onto an undergraduate student. But I remain inordinately proud of my first publication and I find the title quite ironic given my eventual research area (Bevan, C., Roote, J., Russell, S.R.H., Ashburner, M. (1993) 'On the allelism of killer-of-male and male-specific-lethal mutations'. Drosophila Information Service 72: 125). Meanwhile, my introduction to nuclear receptors should have put me off them for life. I missed the relevant lecture, so was hopelessly unprepared when during a tutorial with Gabriel Dover, the proponent of 'molecular drive', I was told to expound on nuclear receptors from first principles. It was not my finest hour and as I recall, it reduced me to tears at one point, but my stubbornness kicked in once again - that may have something to do with the fact that I now spend most of my waking hours thinking, talking and teaching about nuclear receptors!

It was another pioneering fellow of Kings who gave me a push to undertake a PhD - none other than Sydney Brenner - one of the leading figures in the very story that had played a vital role at the start of my university career. I was sitting next to him during a formal dinner at a critical time in my career decision-making process. To him, there was no question 'You should do a PhD at the Laboratory of Molecular Biology' he told me. Whether that was a considered judgement or simply making conversation,
I am grateful for the advice. I didn't follow it to the letter of course: I undertook my PhD at the University Medical School, at the time on the other side of the road from the LMB. It was there that I began working on androgen signalling. I had visited Mark Patterson, who was to become my supervisor, and Ieuan Hughes on the offchance and was fascinated by their work on androgen insensitivity syndrome, in which XY individuals develop phenotypically as undervirilised or wholly female due to lack of response to the normal circulating androgen levels. Who would not find that fascinating - that a simple defect in one gene can subvert off such a complex and fundamental developmental pathway? We managed to find funding and my relationship with the complexities of the androgen receptor - that frustratingly idiosyncratic nuclear receptor - began and continues today. The lab was in the Paediatrics department, based in the hospital, and we had access to patient samples, contact with AIS support groups - it was an introduction to translational work with potential meaningful clinical application and that made everything click into place for me. The intellectual challenge of understanding how something works plus the possibility of using that knowledge to improve things for fellow humans is an addictive mix and I believe what drives us all.

Towards the end of my PhD, in the mid-90s, breast cancer research was at a critical stage with many trials of new hormonal therapies, awareness campaigns and funding drives. Prostate cancer, by comparison, was neglected, and some think it still is. I do not believe, as some do, that the focus on breast cancer has been to the detriment of prostate cancer research - on the contrary, I believe it has benefitted and aided progress in the area enormously as the two have so much in common. These days, conversely, it is refreshingly not unheard of for a breakthrough in prostate cancer research to subsequently be translated to its 'female' counterpart (I use the term advisedly as, of course, male breast cancer is not unheard of) - the steroid synthesis inhibitor abiraterone is a case in point. However, at that time, due to my interest in steroid signalling, I approached Malcolm Parker, then at the ICRF laboratories in Lincoln's Inn Fields (recently morphed into the Crick Institute), who of course is a UK pioneer in nuclear receptor research and most renowned for his work on oestrogen receptor in breast cancer. I did not realise at the time that he had actually started his career working on androgen receptor - luckily for me, he retained sufficient interest in the 'poor relation' to 
take me into his lab where I happily worked with and learned from scientists from every country, exploiting the vast knowledge and excellent resources available and generally getting a great grounding in the mechanics of nuclear receptor signalling. It was an exciting time in the field - coactivators and corepressors had recently been discovered, new ligands were emerging and in some cases entering trials, and the structure of nuclear receptors had been solved to some degree. It was also, of course, my induction into cancer research and what a fantastic place the ICRF was in which to be thrown into the deep end. I gained not only a wonderful mentor in Malcolm (who teaches one to constantly question whatever is in front of you to the nth degree) but also a fantastic cohort of colleagues and friends with whom I remain in contact - some I still work with, others have diverged in their professional paths but we keep in touch and recently all met up to mark Malcolm's retirement. He may have officially bowed out but the productive and collaborative network of nuclear receptor researchers he helped to forge, remains.

Meanwhile a revolution was happening in the world of prostate cancer. Jonathan Waxman, at Imperial College, frustrated by the disparity in funding for this disease, which was now the second biggest cancer killer of men in the West, conceived and set up The Prostate Cancer Charity, the first national organisation dedicated to prostate cancer (it has subsequently become the hugely influential Prostate Cancer UK). I moved to Imperial to set up my group with their support in 1999. I was young to be a PI and I am sure many postdocs now would give a lot to have such an opportunity; however, it was in many ways a baptism of fire and I am ever grateful for the fantastic support (academic and moral) from the colleagues I found there, which enabled me to establish a functional group and rational research programme. As any sensible scientist should, I continue to call on my valued colleagues for input, collaboration and help on a regular basis and (I hope) offer the same to them. We help keep each other sane and on track in the increasingly complex and competitive world of biomedical research. I have also been fortunate to have had some amazing students, postdocs and research assistants over the years. My team have undergone many iterations, of course, and my research programme likewise, but I can distil most of what I have learned about lab management to this - work on what really excites you, with people you like and respect. For one memorable period, my team was entirely female - that had to be addressed, if only because we were at an enormous disadvantage during the annual Movember moustache-growing challenge! In seriousness, camaraderie and a balance of skills and personalities (if not necessarily hormones) is important in any team and I have learned from each and every person who has spent time in my lab.

The field of prostate cancer has flowered in the last couple of decades. It is no longer all about the androgen receptor (although a lot, rightly, is). We now know, as the accompanying review illustrates, that other nuclear receptors are important in this disease, as well as other signalling pathways and there is an astonishing amount of cross-talk and subversion of pathways. Men are living longer with prostate cancer than ever before and the focus now is on treatments that promote better quality of life as well as quantity. The walls that seemed to exist between breast and prostate cancer are dissolving into mist as we understand, for example, the interplay between the different steroid pathways and how androgen and oestrogen receptors - the 'his-and-hers' receptors - are critical in both diseases. I continue to be excited to work on androgen signalling in prostate cancer, but equally excited to have moved into and made contributions in other aspects of the disease, such as the roles of microRNAs, which were unheard of when I started my PhD. Some of our recent work (a transgenic androgen reporter model) has opened up collaborative opportunities regarding the role of androgens in development and disorders thereof, harking back to my time in the Paediatrics department at Cambridge. Another circle in my research journey, which began with male killer genes in Drosophila and is now all about the biggest male cancer killer of all.

This potted history shows my own personal journey so far - hopefully there will be further chapters. Every scientist's journey is different, and everyone's opportunities and interests vary, making it difficult to extrapolate. However, my advice to any aspiring cancer research scientist boils down to: embrace opportunities, collaborate, be tenacious but open-minded, and above all, never lose the curiosity that made you embark on this journey. Oh, and in our field be careful what you say to immigration officers. My first overseas conference was the International Congress on Hormonal Steroids, in Texas. On arrival at Dallas airport, an immigration official asked me the purpose of my journey and, naively, I told him the title of the congress: 'Steroids?' he asked, fingering his gun 'They're illegal, right?' 
Declaration of interest

The author declares that there is no conflict of interest that could be perceived as prejudicing the impartiality of this profile.

\section{Funding}

My work has been supported by Cancer Research UK, Prostate Cancer UK, Movember, the Worldwide Association for Cancer Research, the Medical Research Council of the UK, the Wellcome Trust, Genesis Research Trust, the Harris Family Charitable Trust, the Imperial Experimental Cancer Medicine Centre, Cancer Research UK Imperial Centre, the Whyte Family Charitable Trust, the Rosetrees Trust and The Urology Foundation.

\section{Acknowledgements}

The author thanks all the current and past members of the Androgen Signalling Laboratory and all her colleagues in the Division of Cancer at Imperial.

Received in final form 1 September 2016

Accepted 6 September 2016

Accepted Preprint published online 6 September 2016 